\title{
Interrelasi Kiai, Penghulu dan Pemangku Adat dalam Tradisi Islam Wetu Telu di Lombok
}

\author{
Rasmianto \\ Fakultas Tarbiyah UIN Maulana Malik Ibrahim Malang. Jalan Gajayana No 50 Malang \\ e-mail: rasmianto@yahoo.com
}

Abstrak

Islam Wetu Telu is also Islam, though it is different from traditional avtivities. Islam Wetu Telu is much colored by sincritism among Islamic teaching, Hinduism, and enciunt tradision. These three matters are sigriticantly interrelated to the true history of Islam Wetu Telu as stated by Jalaluddin. Arzaki, the director of internatural and tourism development institution. Another version stated Islam Wetu Telu etablished after the colonial of Belanda in Lombok in 1980 in relations to the strategy to againts the Islam follow of Sasak people.

Key words: Wetu Telu, sincritism, Sasak

\section{Pendahuluan}

Penganut Islam Wetu Telu sebagian besar adalah masyarakat pedesaan yang terisolir dan terbelakang dalam kehidupan. Mereka pada umumnya berdomisili di bagian utara dan selatan pulau Lombok. Namun penganut Islam Wetu Telu yang masih dapat bertahan sampai saat ini hanya di bagian utara pulau Lombok, tepatnya di desa Bayan Kabupaten Lombok Barat dan sekaligus menjadi pusat Islam Wetu Telu. 
Di desa Bayan khusunya masih terdengar denyutan jantung kebudayaan kuno, suatu kebudayaan yang berada jauh di luar dinamika hidup yang menjelma dipelbagai tempat di pulai Lombok. Kebudayaan yang kuno lagi tradisional ini tetap bertahan dan memberikan corak yang khas dan tertentu bagi agama Islam. Kekhasan corak yang diberikannya itu dapat berakibat bahwa orang secara tidak tepat sering memandangnya sebagai suatu kulit luar belaka dan bukan sebagai hasil pengolahan di dalam kebudayaan kuno (Baal, 1976: 7).

Dalam kehidupan sehari-hari, masyarakat Islam Wetu Telu masih tetap berpegang pada tata aturan dan nilai-nilai tradisi lama yang merupakan warisan turun temurun dari nenek moyangnya. Tata aturan dan nilai-nilai tersebut oleh masyarakat Islam Wetu Telu disebut pemaliq (Mandayun, dkk, 1991: 45).

Pemaliq bagi masyarakat Islam Wetu Telu di Bayan, bukan hanya sekumpulan larangan atau pantangan yang sudah baku tetapi juga merupakan aturan main yang harus dipegang dan diturunkan dari satu generasi ke generasi berikutnya. Adanya tata aturan dan nilai-nilai itu dimaksudkan untuk memudahkan hubungan sesama mereka sebagai suatu kelompok yang saling bantu membantu, tolong-menolong dan merupakan kepentingan sosial yang tercermin di dalam adat kebiasaan individu-individunya disebut etika. Etika dapat berarti nilai-nilai dan norma-norma moral yang menjadi pegangan bagi seseorang atau suatu kelompok dalam mengatur tingkah lakunya (Bertens, 1993: 6).

Begitu tingginya mereka memegang adat istiadat warisan leluhur, telah membuat para ulama kesulitan untuk memasuki dunianya. Bahkan, dalam banyak hal, ulama juga kesulitan menanamkan pengaruhnya pada masyarakat ini. Lebih-lebih, banyak juga dari kalangan ulama yang telah lama bermukim di Makkah melalui beberapa generasi.

\section{Sejarah Islam Wetu Telu}

Diketahui bahwa penduduk Lombok Barat mayoritas beragama Islam kecuali suku Bali yang memeluk agama Hindu dan Budha. Sebagian kecil pada umumnya penduduk pendatang adalah pemeluk agama Katulik dan Kristen. 
Masuknya agama Islam di Lombok tidak diketahui dengan pasti siapa yang membawa pertama kali. Ada dua versi yang menyebutkan bahwa agama Islam memasuki pulau Lombok dalam dua aliran sebagai berikut:

1. Dari Makasar lewat Sumbawa kira-kira permulaan abad XVI yang dibawa oleh Sunan Perapen putra dari Sunan Giri. Ajaran ini masuk melalui labuhan Lombok.

2. Dari pulau Jawa lewat Bayan atas instruksi Sunan Penggiang dari Jawa Tengah kira-kira permulaan abad XVI.

Makam Ria oleh masyarakat Bayan sangat dihormati, menurut keterangan Raden Subakti penjaga makam tersebut bahwa, usianya diperkirakan sama dengan masjid kuno tersebut diatas. Terlepas dari adanya perbedaan tentang siapa yang membawa agama Islam ke Lombok, yang jelas masuknya Islam melalui dua aliran itu membawa suatu efek yang kurang baik dalam perkembangan selanjutnya. Sacara tidak langsung Islam pecah menjadi dua aliran yaitu Islam Waktu lima dan Islam Wetu Telu. Islam Wetu Telu berpusat di daerah Bayan sampai sekarang (Fadli, 1998: 79).

Desa Bayan adalah sebuah kecamatan yang terbentang sepanjang pantai utara pulau Lombok dan termasuk daerah yang paling terpencil. Desa Bayan merupakan dataran tinggi di lereng pegunungan Rinjani dengan ketinggian 200 meter dari permukaan laut dan letaknya kurang lebih 80 kilo meter dari Mataram Ibukota Provinsi. Daerah ini menjadi terkenal karena masih menyimpan harta budaya yang ditempat lain di Lombok sudah tidak ditemukan lagi. Seperti masih adanya budaya pembacaan lontar dengan menggunakan bahasa Jawa Kawi. Seperti telah disebutkan diatas bahwa Bayan merupakan pusat penganut Islam Wetu Telu. Asal usul terbentuknya Islam Wetu Telu sampai saat ini masih merupakan misteri, kapan dan siapa yang menamakannya pertama kali. Ada beberapa versi menyebutkan tentang latar belakang munculnya Islam Wetu Telu sebagai berikut. Sebuah versi menyebutkan bahwa Islam Wetu Telu terbentuk bersamaan dengan penyebaran Islam di Lombok. Sebelum tuntas mengajarkan Islam, penyebarnya (wali atau muridnya) dengan sebab yang tidak diketahui meninggalkan Lombok, akibatnya masyarakat yang masih menganut agama Hindu dan Animisme tidak sepenunhnya mampu 
menyerap ajaran Islam. Maka mereka memadukan Animisme, Hindu dan Islam menjadi satu. Perpaduan inilah yang kemudian disebut dengan Islam Wetu Telu. Sesungguhnya penganut Islam Wetu Telu itu sebelah kakinya di Islam dan sebelah lagi Hindu dan Animisme (Sumbogo, dkk, 1991: 62).

Dengan nada yang sedikit berbeda, juga diungkapkan oleh Solichin Salam bahwa dalam menyebarkan Islam, para wali mengajarkan secara bertahap, sewaktu penganut Islam Wetu Telu itu berada pada tahap transisi dari Hindu ke Islam lalu mereka meninggalkan Lombok. Akibatnya tugas mereka belum tuntas dengan sempurna sedangkan para murid-muridnya yang ditinggalkan tidak berani menyempurnakan apalagi merubahnya, sehingga lama kelamaan terjadi penyimpangan dari ajaran Islam yang murni (Salam, 1992: 16). Versi lain menyebutkan bahwa Islam Wetu Telu muncul karena adanya penghinduan yang dilakukan oleh pendeta bernama Dangkian Nirarka yang dikirim oleh Raja Gelgel dari Bali pada tahun 1530. Dengan cerdik pendeta itu mencoba meramu Islam, Hindu dan kepercayaan lama menjadi singkritisme, proses penghinduan ini semakin gencar ketika Raja Gusti Nengah dari Karang Asem Bali menaklukkan kerajaan Seleparang sekitar tahun 1740 (Wacana, 1985: 70).

Berbeda dari versi sebelumnnya, Islam Wetu Telu muncul setelah Belanda menguasai Lombok tahun 1890. Ketika itu Belanda mencari taktik untuk mengalahkan orang Sasak penganut Islam ortodok, maka mereka menciptakan istilah Islam Wetu Telu dengan tujuan untuk merusak dan mengarahkan kepada pertentangan terus-menerus. Sementara itu Raden Gedarip mengatakan bahwa istilah waktu dalam Islam Wetu Telu itu salah penggunaan tetapi yang benar adalah Wetu Telu dengan alasan bahwa Wetu berarti kemetuan dari tiga hal yaitu bertelur, tumbuh dan beranak. Dengan tetap terpeliharanya ketiga hal tersebut maka kesuburan dan kemakmuran di dunia ini akan lestari. Dari beberapa pendapat diatas, yang jelas bahwa Islam Wetu Telu sangat berbau Islam meskipun dalam beberapa acara ritual tampak adanya singkritisme antara agama Islam, Hindu dan ajaran Nenek Moyang. Ketiga hal inilah yang lebih mendekati kebenaran asal-usul Islam Wetu Telu sebagaimana yang diungkapkan oleh Jalaludin Arzaki, Direktur 
Yayasan Kebudayaan dan Pengembangan pariwisasta Nusa Tenggara Barat. Juga versi yang menyebutkan bahwa Islam Wetu Telu terbentuk atau muncul setelah Belanda menguasai Lombok tidak bisa diabaikan karena dalam menyelesaikan beberapa perkara di pengadilan Belanda selalu memenangkan yang bukan Islam Murni.

\section{Falsafah Angka Telu (tiga) dalam Islam Wetu Telu: Melihat Kolaborasi Peran Sosial Kiai Pemangku Adat}

Islam Wetu Telu mempunyai pandangan hidup yang serba Telu (tiga), seolah-olah angka itu merupakan angka sakral. Inilah salah satu yang membedakan antara Islam Wetu Telu dengan Islam ortodok. Al Syahrastani juga menganggap penting al adat (angka) (Syahrastani, 1968: 35).

Rukun Islam yang lima oleh penganut Islam Wetu Telu dipotong menjadi tiga yaitu syahadat, shalat dan puasa pada bulan Ramadhan. Sedangka rukun ke empat dan lima yaitu haji dan zakat mereka tinggalkan, itupun tidak dilaksanakan dengan sempurna. Dalam hal puasa Ramadhan mereka puasa hanya tiga hari pertama, tiga hari pertengahan dan tiga hari terakhir (wawancara, 1999).

Dalam kehidupan bermasyarakat misalnya, sumber hukumnya dibentuk atas dasar tiga perkara yaitu agama, adat dan pemerintah. Oleh karena itu dalam sistem organisasi kemasyarakatan di Bayan mempunyai tiga lembaga yaitu: Pertama lembaga pembantu adat yang menjadi pimpinan tertinggi desa dan biasanya dijabat secara turun temurun. Kedua pembantu pemangku adat yang bertindak sebagai kepala urusan pemerintahan, yang tugasnya menjembatani kepentingan adat dan pemerintah. Ketiga lembaga penghulu yang dijabat oleh seorang kiai. Walaupun mereka mengenal tiga lembaga, seperti tersebut diatas, namun secara garis besar dibagi menjadi dua, yaitu: kehidupan keagamaan dan kemasyarakatan, dengan dipimpin oleh masingmasing petugas. Adapun petugas yaitu sebagai berikut:

\section{Penghulu atau Kiai.}

Masyarakat Wetu Telu mengenal tiga tingkatan kiai yaitu santri, kiai 
raden dan kiai biasa. Kiai santri adalah tingkatan kiai paling tinggi, termasuk didalamnya golongan kiai penghulu yang bertindak sebagai imam masjid, kia Lebai dan kiai Ketip juga kiai Modin sebagai petugas azan. Para kiai di Bayan mempunyai tugas yang penting dan berat, karena mempunyai suatu sistem kepercayaan yang menempatkan kiai sebagai perantara untuk berkomunikasi dengan Tuhan misalnya dalam shalat dan puasa. Mereka menyerahkan pelaksanaan ibadah kepada kiai. Dalam pelaksanaan shalat para kiai pun memperlihatkan ciri khas, misalnya dalam shalat jama'ah terawih di Masjid Kuno para kiai sejajar dengan imam dan disesuaikan dengan tingkat kekiaian mereka. Kiai santri berdiri disebelah kanan imam, kiai Raden berjajar di sebelah kiri imam sedangkan kiai biasa yang tingkat kekiaiannya paling rendah berbaris dibelakangnya (Bertens, 1993: 12).

Begitu pula dalam bulan Ramadhan, para kiai tidak melaksanakannnya selama satu bulan tetapi hanya sembilan hari saja. Namun mereka sangat menghargai bulan Ramadhan, hal ini terbukti dari adanya beberapa pantangan yang tidak boleh dilanggar dalam bulan suci tersebut, yaitu tidak boleh berkata kasar, tidak boleh berkumpul dengan wanita, tidak boleh menyembelih binatang dan tidak boleh bekerja sampai keluar keringat (Bertens, 1993: 18).

Semua kewajiban tersebut di atas, hanya dilaksanakan oleh kiai sedangkan penganut Islam Wetu Telu mempunyai kewajiban taat kepada kiai, mengeluarkan zakat fitrah ketika Idul Fitri tiba yang berupa beras satu purung kelapa dan melaksanakan uapacara-upacara yang berhubungan dengan agama dan adat.

\section{Toaq Lokaq dan Pemangku Adat}

Di desa Bayan istilah Toaq Lokaq merupakan sebutan bagi seseorang yang dituakan bukan dari golongan bangsawan sedangkan Pemangku Adat merupakan sebuatan bagi bangsawan. Namun dalam tugas dan kewajiban, keduanya mempunyai tugas yang sama yaitu menyelenggarakan dan memimpin upacara-upacara yang berhubungan dengan adat. Penganut Islam Wetu Telu mengenal banyak macam upacara, barangkali ini merupakan salah satu ciri khas dari masyarakat tersebut yang tidak dimiliki oleh masyarakat suku Sasak di tempat lain. Pada garis besarnya adat luar gama hidup dan mati (Wawancara, 1994). 
Adat Gama meliputi upacara yang mempunyai hubungan dengan unsur-unsur upacara keagamaan, yakni nampak pengaruh agama Islam. Upacara-upacara adat agama meliputi:

a. Upacara Alip, merupakan rangkaian upacara yang dilaksanakan untuk perbaikan masjid dan makam yang ada. Ada sebuah makam yang sangat dihormati oleh masyarakat Bayan bernama Makam Ria. Penghormatan terhadap makam tersebut mempunyai tujuan untuk mengenang kembali segala petuah dan amalannya sehingga dengan demikian dapat diambil pelajaran yang baik yang disesuaikan dengan keadaan masyarakat. Upacara ini dilaksanakan delapan tahun sekali pada suku tahun pertama dalam sewindu.

b. Upacara Tilawat, merupakan rangkaian upacara yang dilaksanakan dengan maksud memohon kepada Tuhan agar diberikan keselamatan untuk waktu yang akan datang dan diberi ampunan atas segala dosa yang telah diperbuat serta diberikan rizki yang melimpah. Biasanya upacara ini dilaksanakan setelah upacara Alip selesai. Dalam upacara ini diadakan pembacaan al Quran di masjid kuno dengan dihadiri sekurang-kurangnya 44 orang penghulu, kiai dan santri.

c. Lohor Jum'at, upacara ini dilaksanakan dengan maksud memohon rahmat dan keridhoan Tuhan agar seluruh makhluk yang ada di dunia terhindar dari malapetaka. Oleh karena itu upacara ini dilaksanakan tatkala suasana alam dan zaman sedang gawat dan menyedihkan, seperti gunung meletus, gempa bumi dan angin ribut. Pelaksanaan upacara ini dipusatkan di Masjid Kuno yang harus dihadiri oleh 44 orang kiai. Jika jumlahnya kurang dari ketentuan itu maka upacara ini harus dilakukan empat kali jumat berturut-turut.

d. Mulut (dari kata Maulid), upacara ini dilaksanakan untuk memperingati hari kelahiran nabi. Seiring dengan itu, apabila terjadi perkawinan pada malam peringatan tersebut, maka perkawinan semacam itu disebut kawin syari'at. Upacara itu dilaksanakan setahun sekali setiap tanggal 15 Rabiul Awwal. Kegiatan upacara itu biasanya dimulai dengan:

1. Menumbuk Padi. Biasanya dilakukan oleh gadis-gadis dan orang-orang 
setengah baya sebagai pengatur.

2. Tun Gerantung, yakni dikeluarkannya seperangkat alat kesenian pada tanggal 14 Rabiul Awwal berupa dua buah gong, dua buah kelentang dan dua buah gendang kecil. Instrumen tersebut ditabuh semalam suntuk dibarengi dengan peresean di halaman masjid.

3. Menghias masjid dan selamatan Maulud, merupakan acara penutupan menjelang tengah hari pada tanggal 15 Rabiul Awwal diadakan selamatan di dalam masjid yang dipimpin oleh kiai dan santri.

e. Lebaran, upacara dapat digolongkan menjadi tiga yaitu: Lebaran tinggi (Idul Fitri), lebaran ketupat dan lebaran pendek (Idul Adha). Dalam pelaksanaan upacara tersebut masyarakat kelihatan agak pasif, karena seluruh kegiatan upacara dilaksanakan oleh Toaq Lokaq dan kiai santri beserta pembantu-pembantunya. Sedangkan masyarakat hanya memberikan sumbangan berupa beras dan ragi-ragian seadanya.

Selanjutnya, adat luar gama merupakan upacara yang diselengggarakan sehubungan dengan terjadinya musim akibat kemarau panjang atau hujan turun berlebih-lebihan. Upacara ini dilakukan setiap delapan tahun sekali pada suku tahun pertama dalam sewindu, yaitu tahun Alip. Adat tersebut dapat digolongkan menjadi dua jenis upacara yaitu: Taiq Lauq dan Taiq Daya. Upacara Taiq Lauq diadakan tatkala menghadapi perubahan musim kemarau, sedangkan Taiq Daya diselenggarakan manakala menghadapi musim hujan setiap tahunnya (Wawancara, 1998).

Penyelenggaraan upacara besar itu dimaksudkan untuk memohon kepada Tuhan supaya hasil bumi melimpah ruah (gema ripah luh jinawi) dan para petani terhindar dari pengaruh buruk manakala memulai mengolah tanah sawah dan ladang. Apabila sudah tiba waktunya untuk bertanam atau turun ke ladang, biasanya diadakan upacara Mbangar. Upacara ini menunjukkan tempat tertentu di tengah ladang, tempat upacara dilakukan. Di tempat ini ditaruhkan batu kemudian dipagari dengan kayu jarak dan diatasnya dibuat lamin untuk meletakkan sesajen. Tujuan diadakan upacara ini adalah mengusir atau menjinakkan jin, setan dan bakeq beraq supaya para peladang aman dalam pekerjaan. Upacara ini lazim disebut "Toaq Lokaq 
Nggawek Gumi Langit” (Fadli, 1998: 81).

Terkahir, adat hidup dan mati: semenejak kelahiran dan kematian terdapat serentetan upacara-upacara. Didalam kehidupan seseorang terdapat upacara-upacara adat sebagai berikut:

a. Buang au, upacara dilaksanakan menjelang seorang bayi berumur 7 hari kemudian langsung diberi nama.

b. Ngurisan dan Nyunatan, upacara dilaksanakan apabila anak-anak mencapai umur tiga samapai enam tahun.

c. Potong Gigi dan Ngawinan

Begitu pula dalam peristiwa kematian banyak sekali macam upacara bahkan terjadi pengorbanan yang luar biasa karena dianggap sebagai penghormatan terakhir pada almarhum. Kegiatan upacaranya meliputi: penyelenggaraan jenazah seperti memandikan, megafankan, menyalatkan dan menguburkan. Setelah keempat upacara tersebut selesai kemudian menyusul kegiatan lainnya, berupa upacara sebagai berikut:

a. Nelung yaitu hari ketiga dari peristiwa kematian

b. Mituq yaitu hari ke tujuh dari peristiwa kematian.

c. Nyanga yaitu hari kesembilan dari peristiwa kematian. Pada hari ini diserahkan sebagian harta benda almarhum kepada pihak petugas atau acara ini lazim disebut istilah nyelawat.

d. Pelayaran, upacara ini dilaksanakan tiap-tiap minggu atau bulan tepat pada hari kematian sesorang.

e. Matangpulu, nyatus dan nyiu; masing-masing diadakan pada hari yang ke empat puluh, keseratus dan keseribu (Wawancara, 1994).

Menurut Raden Singederia, istilah tiga dalam Islam Wetu Telu tidak ada hubungannya dengan ritualitas keagmaan tetapi pemahaman atas asal usul kejadian manusia. Dia percaya bahwa kelahiran manusia ke atas dunia ini disebabkan oleh adanya tiga sumber, yaitu Tuhan, ayah dan ibu. Dan Wetu Telu sendiri merupakan pengalaman budi pekerti dalam kehidupan sehari-hari. Terlepas dari ada atau tidaknya hubungan tiga dalam Islam Wetu Telu dengan upacara agama, tetapi yang jelas penganut Islam Wetu 
Telu dalam menjalankan upacara selalu bertumpu pada angka tiga atau tiga hal, seperti dalam ibadah, mereka mengenal tiga macam ibadah besar yaitu Loh Langgar, Loh Dewa (Penyembah terhadap Dewa) dan Loh Makam (penyembah terhadap leluhur). Juga mereka hanya melaksanakan tiga macam shalat yaitu shalat Idul Fitri, Shalat Idul Adha dan Shalat Jum'at besar (Sumbogo, 1991: 63).

Jadi makna Telu dalam Islam Wetu Telu mempunyai kaitan dengan asal usul kejadian manusia dan juga erat hubungannya dengan acara ritual keagamaan yang dipercayai dan dilakukan oleh penganut Islam Wetu Telu.

Disamping itu angka telu dalam istilah Wetu Telu mempunyai kaitan dengan sistem lapisan yang ada dalam masyarakat Sasak di Bayan. Secara umum ada dua macam lapisan masyarakat di Bayan yaitu perwangsa dan jajar karang (Salam, 1992: 17). Perwangsa merupakan lapisan orang-orang bangsawan dan patih. Golongan bangsawan sendiri dibagi menjadi dua yaitu bangsawan kelas tinggi dan kelas menegah. Jajar karang adalah lapisan orang-orang biasa (rakyat jelata). Jadi dalam peraktiknya masyarakat di Bayan mengenal tiga lapisan masyarakat, demikian diuangkapkan oleh Raden Gedarip. Lebih lanjut dijelaskan bahwa sistim lapisan tersebut merupakan warisan yang diberikan oleh orang tua mereka (Wacana, 1985: 77).

Untuk mengetahui bahwa seseorang itu bangsawan atau tidak, dapat diketahui dari gelar yang disandangnya ke dalam lapisan mana ia tergolong. Gelar itu diperoleh menurut garis keturunan laki-laki yang sepihak (Patrilineal). Gelar Raden adalah sebutan untuk laki-laki bangsawan kelas tinggi dan Dende untuk sebutan bagi perempuan, kemudian gelar Lalu adalah sebutan untuk bangsawan kelas menengah sedangkan Baiq untuk sebutan bagi perempuan dan Amaq sebutan untuk laki-laki sedangkan Inaq sebutan untuk perempuan jajar karang. Walaupun gelar-gelar tersebut tidak memisahkan golongan atau lapisan masyarakat secara ketat, akan tetapi sangat penting artinya dalam sopan santun dan pergaulan sehari-hari. Sistim lapisan tersebut sangat jelas terlihat dalam perkawinan. Seorang gadis dari golongan bangsawan tidak boleh kawin dengan seseorang dari golongan yang lebih rendah. Apabila hal ini terjadi, biasanya pihak laki-laki membayar denda dan gadis tersebut 
dibuang dari keluarganya (Wacana, 1985: 81).

Pembagian masyarakat menjadi golongan-golongan tersebut juga sangat berpengaruh di dalam bahasa pergaulan sehari-harinya. Pada umumnya, bahasa Sasak dibagi menjadi dua yaitu bahasa halus dan bahasa biasa. Bahasa halus dipergunakan untuk berbicara dengan orang yang lebih tua, biasa digunakan dalam bahasa sehari-hari dalam pergaulan dengan orang-orang biasa. Dalam hal berbahasa, masyarakat Sasak di Bayan mempunyai aturan-aturan dalam arti siapakah orang yang diajak bicara itu. Kalau orang yang diajak bicara itu lebih tua maka hendaknya menggunakan bahasa halus seperti seorang anak dipanggil orang tuanya, maka ia harus menyahut dengan kata 'Napi' sedangkan menyahut panggilan orang sebaya menggunakan kata 'Ape'. Ini menunjukkan bahwa suku Sasak di Bayan mempunyai rasa hormat, sopan santun dengan sesama. Dalam kehidupan sehari-hari masyarakat Islam Wetu Telu yang bangsawan dengan golongan masyarakat desa tampak suatu perbedaan yang sangat menjolok, terutama dalam hal peranan dan kedudukan. Mereka golongan bangsawan mempunyai kedudukan tinggi dalam masyarakat sedangkan mereka yang bukan bangsawan tidak mempunyai kedudukan, misalnya menjadi Toaq Lokaq atau pemangku, namun tetap tingkat kepemangkuannya lebih rendah (Wawancara, 1998).

Desa Bayan sebagai pusat Islam Wetu Telu hanya sebuah kampung kecil yang terbagi menjadi empat bagian oleh simpang empat. Disebelah tenggara terdapat gubug (kampung) bangsawan Bayan Timur (timuq) dan sebelah barat daya terdapat gubug bangsawan Bayan Barat. Gubug ini terbagi menjadi pelawangan dan karangsalah. Pembagian desa Bayan menjadi dua tersebut mempunyai hubungan antara kekuasaan rohani dan kekuasaan duniawi. Pemangku dari Bayan Timur disebut pemangku Beleq atau agung mengurusi bidang agama sedangkan pemangku dari Bayan barat mengurusi masalah adat luar gama. Mereka menduduki jabatan pemangku secara turun temurun.

Akan tetapi kanyataan Bayan Barat memang lebih rendah tingkat kedudukannya dari Bayan Timur. Hal itu nampak jelas pada kesempatan Ngaji Makam. Para utusan Bayan Barat menunggu di luar masjid kuno sampai utusan dari Bayan timur datang dengan membawa pelbagai persembahannya kepada 
penghulu atau kiai. Ketika mereka berada dalam masjid baru kemudian para utusan dari Bayan Barat masuk. Menurut Raden Murki salah seorang penjaga Masjid tersebut memang utusan dari Bayan Timur harus lebih dahulu karena menurut sejarahnya Bayan Timur merupakan tempat kedudukan Raja-raja Bayan sedangkan Bayan Barat tempat kedudukan Pepatihnya. Anggapan ini masih dipertahankan hingga kini (Syahrastani, 1968: 19).

Perbedaan pemangku Bayan Barat dan Bayan Timur, juga jelas terlihat pada tempat tingggalnya yang memiliki beberapa Berugag (sebuah bangunan kecil tiada berdinding). Berugag itu befungsi untuk berkumpul, menerima tamu dan sebagai tempat untuk persiapan ketika akan melaksanakan suatu upacara. Oleh sebab itu Berugag tersebut mempunyai nama yang khusus. Ada yang dinamakan Berugag Agung, dipergunakan sebagai tempat berkumpulnya para pemangku setiap kali mengadakan musyawarah atau gundem, Berugag Malang dan Empaq sebagai tempat mengolah daging untuk keperluan upacara.

Walaupun ada perbedaan tingkat kedudukan tidak berarti bahwa mereka dapat bertindak semaunya tetapi penganut Islam Wetu Telu tetap memegang prinsip musyawarah atau gundem dalam segala hal yang berkaitan dengan orang banyak. Masyarakat Islam Wetu Telu merupakan masyarakat yang penduduknya hidup terpencar-pencar di dalam kampung kecil. Setiap kampung dihuni oleh sekitar 40 kepala keluarga, seperti terdapat di desa Senaru dan Sukadana dan ada yang lebih kecil dari jumlah itu. Itu menunjukkan bahwa masyarakat Islam Wetu Telu merupakan masyarakat yang terkotak-kotak tetapi mereka masih tetap memegang prinsip "Telu Warne Sopoq Daerah" (Wawancara Lombok Pos, Tanggal 20 September 1994 dengan Jalaludin). Walaupun masyarakatnya hidup terpencar-pencar tetapi rasa persaudaraan tetap dijunjung tinggi. Hal itu dapat dibuktikan ketika mereka mengadakan upacara di Masjid Kuno.

Dalam hidup bermasyarakat penganut Islam Wetu Telu selalu mengacu pada ajaran-ajaran yang ada dalam lontar. Pada lembaran-lembaran lontar itu banyak ditulis mengenai ajaran-ajaran tentang kehidupan, filsafat, agama dan sampai ke cerita-cerita rakyat. Seperti contoh lontar kotaragama yang berisi masalah hukum. Dari budaya lontar inilah lahir tata nilai bermasyarakat yang disebut Pemaliq (pantangan). Pemaliq atau pantangan bagi masyarakat suku 
Sasak di Bayan bukan hanya sekumpulan larangan yang telah baku tetapi juga aturan main yang harus dipegang dan diturunkan dari satu generasi ke generasi berikutnya (Wawancara, 1999). Lebih lanjut dia menerangkan bahwa pemaliq yang menurut hukum adat tidak boleh di langgar mempunyai beberapa tingkatan yaitu:

1. Sora Kanggo Tebait. Ini adalah pemaliq tingkatan paling ringan, adapaun perbuatan yang termasuk dalam pemaliq ini seperti memakan daging babi, menjelek-jelekkan orang lain.

2. Pemaliq Tingakatan Kedua disebut pemalik saja. Termasuk dalam larangan ini misalnya melanggar perintah orang tua yang mengarah pada perbuatan anak durhaka, kawin dengan saudara kandung. Bagi yang melanggar larangan ini diusir atau disisihkan oleh masyarakat.

3. Pemaliq Leket yakni pantangan yang memiliki tingkat paling keras. Termasuk dalam larangan ini antara lain: menghilangkan nyawa orang lain dan berzina. Bagi orang yang melakukan perbuatan ini hanya ada satu hukumannya yaitu mati. Perbuatan mencuri juga termasuk katagori pemalik leket. Orang yang ketahuan mencuri diusir dari kampung. Di samping itu menyihir atau neloh dengan tujuan mengilangkan nyawa orang lain merupakan salah satu pantangan paling keras. Hukumannya adalah hukum mati atau diusir dari kampung.

Dengan adanya tata nilai atau aturan masyarakat tersebut maka tidak heran angka kriminalitas di daerah Bayan sangat rendah. Hal itu diakui oleh Raden Gonda Kusuma Kepala Desa Bayan (Wawancara, 1998).

Jadi dari penjelasan di atas nampak bahwa angka telu dalam Islam Wetu Telu merupakan angka sakral bagi masyarakat Bayan. Hal itu terbukti mulai dari asal kejadian manusia, sistem kepercayaan, lapisan masyarakat, upacara-upacara dan sampai tata aturan masyarakat merujuk kepada angka telu.

\section{Wetu Telu Vs Ulama-Ulama Sasak}

Sebenarnya sejak kapan istilah Tuan Guru populer di Gumi Sasak ini? Menurut penelitian Drs.H. Lukman Al Hakim, MM, yang kini menjadi Ketua 
Sekolah Tinggi Agama Islam Negeri (STAIN) Mataram mengungkapkan bahwa istilah Tuan Guru di L dikenal sejak abad ke-19. Sebelumnya, sejak abad ke-17 ketika jayanya Kerajaan Islam Sasak seperti Kerajaan Selaparang Lombok Timur dan Kerajaan Pejanggik di Lombok Tengah, masyarakat menyebutnya sebagai seorang 'guru', khususnya bagi seseorang yang memiliki pengetahuan agama Islam ang lebih baik. Pasalnya, saat itu, tugas mereka memang seperti guru biasa yang mendidik anak-anak atau remaja-remaja Islam tentang ilmu agama yang bertempat di rumahrumah atau juga di santren-santren (mushalla). Materi pengajiannya pun mulai dari yang sangat praktis dengan cara yang sederhana. Seperti tauhid, fiqih dan ilmu tasawuf.

Memasuki abad ke-18, kerajaan Hindu Bali yang semula bermarkas di Lombok Barat, Cakranegara, mulai menginvasi kerajaan-kerajaan Islam dan menguasainya. Sehingga, pengajian-pengajian yang dikembangkan oleh para guru tersebut sedikit-demi sedikit meredup. Padahal saat itu, pihak penguasa, Hindu Bali, saat itu tidak melarang penduduk asli Suku Sasak menganut agama yang berbeda dengan pihak 'penguasa'. Namun, bagaimana pun bayang-bayang kolonialis tetap saja memiliki pengaruh terhadap kehidupan beragama penduduk saat itu. Maklum, kerajaan Hindu Bali cukup lama bercokol di pulau ini, sejak tahun 1740-1894 (Cederoth, 1981: 155).

Setelah berakhirnya penguasaan Kerajaan Hindu Bali ini, kran bagi pembelajaran agama Islam secara lebih baik. Penduduk asli sudah ada yang melakukan ibadah haji sambil belajar agama, khususnya kaum muda Sasak saat itu. Diantara Tuan Guru pada akhir abad ke-19 yang turut menentang keras keberadaan Wetu Telu di pulau Lombok saat itu yang cukup dikenal luas adalah TGH. Umar Kelayu Lombok Timur. Di Lombok Barat muncul beberapa orang Tuan Guru yang cukup disegani saat itu seperti; TGH. Ahmad Kediri, TGH. Amin Sesila, TGH. Mustafa Sekarbela, TGH. Abdul Hamid Pagutan. Mereka adalah para tuan guru yang memiliki jamaah yang sangat besar saat itu, terutama TGH.Umar Kelayu. Konon, tuan guru yang lahir awal abad ke-19 dan meninggal pada akhir abad ke-19 ini memiliki jamaah paling besar diantara tuan guru yang ada saat itu. Dalam beberapa cerita Sasak, 
tuan guru ini dikenal karena pemurah dan penyayang kepada para jamaahnya.

Salah satu saudara TGH. Umar adalah TGH. Usman. Murid TGH. Mustafa Sekarbela dan TGH. Amin Sesila ini, pada saat memasuki umur 14 tahun sudah hijrah ke Makkah untuk mendalami ilmu agama. Tepatnya di Masjidil Haram. Setelah 15 tahun lamanya bermukim di Masjidil Haram, TGH. Usman mengabdi menjadi guru. Tercatat beberapa muridnya yang berasal dari L yang menjadi besar. Sebut saja seperti; TGH. Rais Sekarbela, TGH. Abdul Hamid Pejeruk, TGH. Asyari Sekarbela, TGH. Ahmad Mali Pagutan, TGH. Abdul Karim Praya, TGH. Syaifuddin Pancor, TGH. Muhammad Ali dan TGH. Abdullah Kelayu serta TGH. Zainuddin Tanjung. Para tuan guru yang sekaligus murid TGH. Usman di atas, dalam faktanya, merupakan para penggerak agama yang disegani di Lombok.

Di antara tuan guru-tuan guru yang segenerasi dengan para tuan guru di atas, tercatat seperti TGH. Mukhtar dan TGH. Abdul Hamid Kediri, TGH. Arif Mesangguk, TGH. Mustafa Gegutu, TGH. Muhammad Sholeh Hambali Bengkel, TGH. Ma'sum dan TGH. Ma'oen Praya dan lain-lain. Mungkin, dalam jarak yang tidak terlalu lama, maka muncul kembali beberapa tuan guru lainnya yang kemudian memiliki gerkan pendidikan yang sampai saat ini masih berkembang dengan baik. Taruhlah seperti TGH. M. Zainuddin Abdul Madjid Pancor (Maulana sendiri) yang banyak melakukan terobosan dalam dunia pendidikan dan dakwah di Lombok. Hampir disetiap dusun, hingga yang terpencil pun, akan ditemukan madrasah binaannya. TGH. Muhammad Shaleh Hambali adalah tokoh NU NTB pertama di Lombok. Beliau berhasil membuka lembaga pendidikan sebelum kemerdekaan dengan nama Perguruan Darul al Quran. Menurut murid kesayangannya yang juga tokoh NU nasional, TGH. LM. Turmudi Badruddin, TGH. Shaleh Hambali dikenal dengan penguasaannya dalam bidang ilmu al Quran.

Begitu juga dengan tuan guru kakak beradik, TGH. Mustafa Khalidy dan TGH. Ibrahim al Khalidy yang mendiriak Pondok Pesantren al Islahuddiny. Pesantren ini juga tidak kalah hebatnya. Beberapa tuan guru besar lahir juga dari pesantren ini. Maklum, kakak beradik ini dikenal sangat rajin dan disiplin dalam mengajar para santrinya.Yang tak kalah hebatnya adalah 
TGH. Hafidz Suliman Kediri, TGH. Mahsun Masbagik, TGH. Zainuddin Arsyad Mamben. Mereka semua juga memberi warna tersendiri dalam peta pembangunan umatnya. Dari sekian nama tuan guru di atas, mungkin yang paling menarik adalah munculnya TGH. A. Haris. Karena beliau tampil beda dengan menjadi Muballigh Muhammadiyah di Lombok. Selama hidupnya tidak pernah memimpin santri atau mendirikan pesantren sebagaimana layaknya para tuan guru di Lombok.

\section{Daftar Pustaka}

Baal, J. Van. 1976. Pesta Alip di Bayan. Jakarta: Bharatara.

Bertens, K. 1993. Etika. Jakarta: Gramedia.

Cederoth, Sven. 1981. The Spell of the Ancestors and the power of Makkah: a Sasak Community on Lombok. Universitatis Gothoburgenesis. tp.

Fadli, 1998. Etika Masyarakat Wetu Telu. Skripsi. STAIN Malang.

Mandayun, Rustam F; Abidien, Zed; Khafid,Supriyanto. 27 April, 1991

Benteng Terakhir Budaya Sasak. Tempo. Halaman 45.

Syahrastani. 1968. Al-Milal wa al-Nihal. Juz I. tp.

Sumbogo, Priyono B; Abidien, Zed dan Mandayun, Rustam F. 27 April,1991. Ahli Waris Jawa Majapahit. Tempo. Halaman 62.

Salam, Solichin. 1992. Lombok Pulau Perawan. Jakarta: Kuning Mas.

Wacana, Lalu. 1985. Sejarah Nusa Tenggara Barat. Jakarta: Departemen Pendidikan dan Kebudayaan.

Wawancara, 2 September 1998 dengan Raden Gedarip.

Wawancara, 2 September 1999 dengan Jalaludin Arzaki di Bayan.

Wawancara Lombok Pos, Tanggal 20 September 1994 dengan Jalaludin. 
Wawancara Lombok Pos, 5 Oktober 1994 dengan Raden Gedarip.

Wawancar, 20 September 1998 dengan Najamudin

Wawancara Majalah Tempo, 3 September 1998 di Bayan.

Creifharakah, Vol. 11, No. 2, Tahun 2009 